\title{
Wspomnienie o Andrieju Bazilewskim
}

DOI: http://dx.doi.org/10.12775/RP.2019.024

Piątego maja 2019 roku w Moskwie zmarł profesor Andriej Borisowicz Bazilewski, slawista, polonista, pracownik Instytutu Literatury Światowej Rosyjskiej Akademii Nauk, a ponadto poeta, tłumacz z języka polskiego i serbskiego, założyciel wydawnictwa Wahazar.

Bazilewski urodził się 24 czerwca 1957 roku w Kałudze. W 1978 roku ukończył filologię słowiańską na Uniwersytecie Moskiewskim. W 1985 obronił rozprawę doktorską poświęconą twórczości poetyckiej Juliana Tuwima, a w 2000 habilitację o grotesce Stanisława Witkiewicza. Od 1987 roku był wykładowcą Instytutu Literatury Światowej Rosyjskiej Akademii Nauk.

Jako naukowiec Bazilewski publikował prace poświęcone głównie literaturze polskiej i serbskiej, współredagował m.in. prace naukowe o rozwoju kierunków literatury światowej w XX stuleciu, o awangardzie literackiej (2010), pracował nad powstaniem encyklopedycznych słowników surrealizmu (2007) i ekspresjonizmu (2008).

Jako tłumacz przekładał z polskiego i serbskiego - w jego tłumaczeniach bądź pod jego redakcją w Rosji ukazało się ponad 30 książek pisarzy polskich, w tym po raz pierwszy publikowany po rosyjsku Witkacy. To właśnie w przekładzie Bazilewskiego na scenach rosyjskich teatrów pojawiły się sztuki tego polskiego autora. Wyrazem fascynacji dla niego stała się również nazwa założonego w 1991 roku wydawnictwa Wahazar, które miało służyć popularyzacji literatur słowiańskich i realizowało projekty Bazilewskiego - antologisty, takie jak „Biblioteka Slawistyki”, „Kolekcja Literatury Polskiej”, „,Rosyjsko-polska Biblioteka poetycka”, „Kolekcja Literatury Serbskiej”, „Serbsko-rosyjska Biblioteka Poetycka”, „Rosyjsko-serbska Biblioteka Poetycka” czy almanach „Serbski Krąg”. W ramach tych serii ukazywały się zbiory poezji polskiej oraz serbskiej, a także dwujęzyczne tomy wierszy zawierające tłumaczenia w obrębie polskiego, serbskiego i rosyjskiego. Uczony był tu jednocześnie wydawcą, redaktorem i jednym z tłumaczy.

Znany był również jako poeta. Opublikował kilka autorskich tomików poetyckich, a jego wiersze przekładano na inne języki. Ostatnio współpracował z czasopismem „Krytyka Literacka”, dla którego wybierał teksty współ- 
czesnych rosyjskich poetów, opatrując je komentarzami pod wspólną nazwą „Odpryski tęczy. Współczesna poezja rosyjska”.

Współpracowaliśmy przy tomie „polskiej Cwietajewej”, do którego mnie zaprosił. Spotkaliśmy się w grudniu 2018 roku w Moskwie, piliśmy herbatę, rozmawialiśmy o tłumaczeniach... Do końca życia pisał, przekładał, wydawał, służąc, jak mówił o swoim wydawnictwie: „porozumiewaniu się ponad zakazami, które znowu się pojawily".

W ostatnich latach zmarło kilkoro rosyjskich tłumaczy z języka polskiego, twórców przyczyniających się do tego porozumienia. Po śmierci Asara Eppela w 2012 roku, a następnie Światosława Świackiego i Kseni Starosielskiej w 2017 roku, odejście Bazilewskiego to kolejna niepowetowana strata dla kultury rosyjskiej i polskiej. A mnie osobiście będzie brakowało jego serdeczności i redaktorskich rad mądrego, ciepłego, dobrego człowieka, jakim był Andriej Bazilewski.

Anna Bednarczyk

Uniwersytet Łódzki anbednar@o2.pl

\section{Andriej Bazilewski}

Rien ne va plus

A kiedy będę martwy, biały

i w niebie pełnym śmierci,

to głuchonieme „nigdy więcej”

w rozbrzmiewającej pustce

spadnie na moją biedną głowę

kamieniem przezroczystym

ciszy, co piękny jak nadzieja

- i w wieńcu napalmowym,

ostatni sen odleci gdzieś

w zieloną przestrzeń okna,

wierzchem na tęczy ...

Leżę na wznak z rozbitą głową

Pod różnobarwnym niebem,

Nade mną przelatują klucze,

Do których nie ma drzwi.

2.

Kiedy ogrodnik zły jak bies

wezwie do odpowiedzi, 
a wiecznych jabłek zapach w mózg

uderzy z całą mocą

wybiorę dla nas pośród gwiazd

planetę zagubioną:

i naszych bliskich spotkam tam,

spadniemy więc z wysoka

niebieską dryndą, lecąc w dół

po białym polu ślizgiem

w liliowe baptysterium.

Tam z wolna wzejdzie ponad nas

świecidło papierowe

i bladą świecę zgasi wnet

wesoła zawierucha.

3.

Gdy się upiję, gasząc strach, bohater w blasku chwały, jak bóg okrutny i niezłomny zwali mnie jednym przytykiem, gdy nie dam rady pić do dna przysięgę swoją pójdziesz dać już z innych prawd prorokiem, on wie jak wejść i wie jak wyjść, zna serca tajemnice,

udrękę uczuć zna i wie,

czemu u raju stojąc bram

do „piekła”

chcemy wrócić.

Tłum. Anna Bednarczyk

\section{Obcy pogrzeb}

Piątek jest próżny. Już bez słów

w popiół się wszystko obróciło.

Różowolicy świat jest zdrów, nic się w nim wcale nie spaliło.

Tylko papieros twój jak gwóźdź powietrze rani i rozdziera:

„Donikąd nam nie spieszno teraz

- odejdźmy już”

Tłum. Anna Bednarczyk 